\title{
Redefining success: the political ecology of genetically modified and organic cotton as solutions to agrarian crisis
}

\author{
Andrew Flachs ${ }^{1}$ \\ Washington University in St. Louis, USA
}

\begin{abstract}
The transnational spread of law and technology in Indian agricultural development has passed through three distinct phases since the mid- $19^{\text {th }}$ century. In each case, a narrative of agrarian crisis allowed for new state and corporate interventions, conceived by American and British agribusiness, within the existing logics of Indian smallholder agriculture. These begun with colonial British industrial cotton projects in the 1840s, continuing with Green Revolution agriculture, and on contemporary GM and organic cotton farms. In each case, farmers developed strategies through a frictive, contentious adoption of new technologies and built new avenues to success that worked for some farmers and failed for others. In this article I draw on ethnographic fieldwork and household surveys conducted in nine villages from 2012-2014 in Telangana, India. As with previous development initiatives, the US-born legal structures that defined high-tech GM and low-tech organic agriculture were adopted in India without major changes. I argue, however that their actual implementation by farmers has required a significant shift in the ways that people manage the agricultural economy.
\end{abstract}

Keywords: Genetically Modified crops, organic agriculture, development, South India

\section{Résumé}

La diffusion transnationale de droit et de la technologie dans le développement agricole indien a passé par trois phases distinctes depuis le milieu du 19ème siècle. Dans chaque cas, un récit de la crise agraire a permis de nouvelles interventions de l'Etat et des entreprises, conçu par l'agro-industrie américaine et britannique, dans les logiques existantes de la petite agriculture indienne. Ceux-ci commencé avec des projets de coton industriel britanniques dans les années 1840, la poursuite de la révolution verte, et avec l'utilisation contemporaine des variétés GM et le coton biologique. Dans chaque cas, les agriculteurs ont développé des stratégies grâce à une adoption controversée de nouvelles technologies et construit de nouvelles avenues à succès qui ont travaillé pour certains agriculteurs et échoué pour d'autres. Dans cet article, je tire sur des enquêtes de terrain et des ménages ethnographiques menées dans neuf villages 2012-2014 dans Telangana, en Inde. Comme avec les initiatives de développement antérieures, les structures juridiques des États-Unis qui ont défini de haute technologie (GM) et low-tech (agriculture biologique) ont été adoptées en Inde sans changements majeurs. Je soutiens cependant que leur mise en œuvre par les agriculteurs a nécessité un changement important dans la façon dont les gens gèrent l'économie agricole.

Mots-clés: cultures génétiquement modifiées, l'agriculture biologique, le développement, Inde du Sud

\section{Resumen}

La difusión transnacional de las leyes y la tecnología en el desarrollo agrícola en India ha tenido tres fases desde la mitad del siglo XIX. En cada caso, una narrativa de crisis agraria permitió nuevas intervenciones estatales y corporativas, concebidas por la industria agraria estadounidense y británica, en la lógica existente de la pequeña agricultura india. Estas intervenciones comenzaron con proyectos coloniales industriales

\footnotetext{
${ }^{1}$ Andrew Flachs, PhD Candidate, Washington University in St. Louis, 1 Brookings Drive, St. Louis, MO 63130, USA. Email: aflachs "at" wustl.edu. The author wishes to thank the JPE editors, Simon Batterbury, Brian Burke, the Eric Wolf Prize Selection Committee, and three anonymous reviewers for their helpful comments. This project was funded in part by the Jacob K. Javits Fellowship, the John Templeton Foundation (Glenn Davis Stone PI), the National Geographic Society Young Explorer's Grant, the Lynne Cooper Harvey Fellowship, and the William L. Brown Center at the Missouri Botanical Garden. Additional logistical support was provided by Ram Mohan Rao and Glenn Davis Stone. Finally, the author is grateful to the farmers, crop scientists, shop owners, and NGO workers for their patience and help in describing their daily lives and work. This paper was winner of the Eric Wolf Prize, Political Ecology Society, 2015.
} 
británicos con algodón en la década de 1840, continuaron con la agricultura de las Revolución Verde, y se manifiestan en las actuales granjas de algodón genéticamente modificado u orgánico. En cada caso, los agricultores desarrollaron estrategias mediante la adopción conflictiva y polémica de nuevas tecnologías y construyeron nuevas vías hacia el éxito que han funcionado para algunos agricultores y fracasaron para otros. En este artículo me baso en encuestas etnográficas de trabajo de campo y en hogares realizadas en nueve pueblos de Telangana, India, entre 2012 y 2014. Al igual que con iniciativas de desarrollo anteriores, las estructuras legales procedentes de Estados Unidos que definían la agricultura de alta tecnología genéticamente modificada y la agricultura orgánica de baja tecnología se adoptaron en la India sin cambios importantes. Sin embargo, argumento que su aplicación efectiva por los agricultores ha requerido un cambio significativo en la forma en que la gente maneja la economía agrícola.

Palabras clave: cultivos genéticamente modificados, agricultura orgánica, desarrollo, sur de la India

\section{Introduction}

India's Agricultural Needs are Rising (Monsanto India Website, 2012)

We choose villages which are in deep crisis. That's the first target we have. (Organic Agriculture NGO Director, 2014 interview)

Through the late 1990s, Indian cotton farmers suffered a troubling rise in bollworm pests, pesticide use, debt, and suicides. Depending on the disciplinary focus of commentators, these problems have been described as acute, with plant scientists and some economists focusing on local crop failures and poverty (Qaim 2010; Qaim and Zilberman 2003; Vaidyanathan 2006), or chronic, with anthropologists and social historians looking for explanations further afield in global systems of capital or power (Deshpande and Arora 2010; Galab, Revathi, and Reddy 2009; Stone 2011). The crisis captured international headlines, although it was not necessarily new in India, and there was no clear link between suicide and agrarian distress (Plewis 2014). Roitman (2013) has argued that a crisis may be named in order to shape a narrative, for particular political and economic purposes. In India, agrarian crisis, apolitically characterized as an overabundance of cotton pests and chemicals, opened the door for two legally exclusive technological solutions: Genetically modified (GM) Bt cotton and organic cotton. ${ }^{2}$

Political ecology asks that we consider seemingly natural events, including the trajectory of agricultural technology, as part of a historical and social process (Blaikie 1985; Robbins 2004). By focusing on the ways in which political and economic interests shape agricultural development interventions, political ecology illuminates, for example, the ways in which food aid was used as a tool of Cold War geopolitical alignment (Cullather 2013; Perkins 1997), or how the regulation of new agricultural technologies emerged from complex legal negotiations (Jasanoff 2005).

A political ecology analysis has shown that debates over GM crops are frequently based on moral, interpretative judgments about the role of technology in society, although they often couched by their proponents as simple and naturally superior technologies (Schurman and Munro 2010). It also suggests that institutional changes in agricultural reward structures influence daily agricultural practices. Cotton farming in India has passed through three defining phases since its commercialization by the East India Company: the colonial period, followed by the Green Revolution, and genetically modification. Each stage has been characterized by a push toward profit and the consolidation of knowledge further from the fields and among off-farm experts. Globally, a smallholder logic based on flexible market-orientated and subsistence farming has gradually been displaced by an industrial rationality stressing management, investment, and profit

\footnotetext{
${ }^{2}$ Bt refers to Bacillus thuringiensis, a naturally occurring soil bacteria that produces toxins poisonous to insects in the order Lepidoptera, which includes cotton bollworms. Seven different Cry genes have now been inserted into GM cotton in various combinations, allowing the plant to produce its own insecticide.
} 
maximization (Brookfield 2001; Fitzgerald 2003; Netting 1993). Despite their profound differences, organic and GM agriculture both offer farmers a foreign technology managed by experts external to the household. GM proponents argue that modified seed is an ideal technology because it is self-contained, "easy to manage", and requires no significant changes for farmers (Qaim and Zilberman 2003; Thaindian News 2008). In 2002, Bt cotton required no deviation from existing agricultural logics: purchase chemical inputs, use seeds developed by biotechnology corporations, and produce cash crops. Indeed, the externally developed benefit of Bt cotton, namely less pesticide application, assume that farmers require less, not more, knowledge to grow this crop successfully. Organic agriculture positioned itself as the alternative to input- and capital-intensive agriculture. Through organic farming, which explicitly prohibits the use of GM technology, farmers appeal to niche markets and balance lower production with lower overall costs. Proponents of certified organic agriculture seek to eliminate environmentally destructive management practices by educating famers about international standards. Although this teaching can incorporate local experts (Mancini, Van Bruggen, and Jiggins 2007), the resulting farm management must conform to regulations developed by the USDA (Narayanan 2005). To align with legislation already used in textile marketing, the US-born legal structures that defined GM and organic agriculture were adopted in India without major changes. However, their actual implementation by farmers has required a significant shift in the ways that people manage the agricultural economy.

In this article I argue that GM and organic cotton reflect a continuation of agricultural development driven by US policies since the late $19^{\text {th }}$ century. While the discourse of agrarian crisis implies that organic and GM agriculture offer something new for Indian farmers, cotton production in the United States and India have been connected through botanical, economic, regulatory, and political links since the American Civil War (1861-1865). In each phase of cotton development, changes in regulation, marketing, and seed varieties created new incentives for farmers. To explore how farmers are reacting to changing reward structures, I draw on household seed surveys and ethnographic research conducted from 2012-2014 among nearly 500 farmers in three organic cotton-producing and six GM cotton-producing village clusters of households in Telangana, India (Figure 1). ${ }^{3}$ Surveys were designed to collect information about particular cotton seeds planted by the farmers. Respondents were randomly selected from a wealth-stratified census to represent poor, middle-income, and wealthy people belonging to a representative sample of castes. I spoke to farmers in these nine villages because they represent a range of socioeconomic diversity, ethnic makeup, and proximity to cities while still having similar agricultural conditions, all of which are important elements in the agricultural decision-making process. These three organic village clusters additionally allowed me to speak to farmers involved with certified and non-certified organic agriculture. In addition to seed surveys and participant-observation in fields and seed shops, I also held focus groups and conducted in-depth interviews with various stakeholders in cotton agriculture including shop owners, farmers, extension scientists, and seed brokers.

The colonial and later postcolonial political economy established a flow of resources and expertise between the United States and India (Beckert 2014; S. Guha 2007; R. Guha 2008; Perkins 1997), setting the stage for the current spread of organic and GM technologies into India. However, these agricultural regimes have wrought significant changes for Telangana farm work because they changed the agricultural reward structure for local farmers. To presume that the adoption of new technology, ranging from GM seeds to organic compost is a natural communal response obscures the complex interactions of personality, opportunism, alliance, oppression and social stratification of daily life in agrarian India (Agrawal and Sivaramakrishnan 2000) and thus of the daily practice of agricultural knowledge. This contentious, neverfinished process ultimately determines how new technology is used amidst confusion, risk, and uncertainty as I will show below.

\footnotetext{
${ }^{3}$ The Telangana region of Andhra Pradesh is a historically underdeveloped region in South India. After more than fifty years of demonstration against the diversion of natural and social resources to coastal and Southern regions of the state, Telangana was granted independent statehood by India's central government in 2014 .
} 


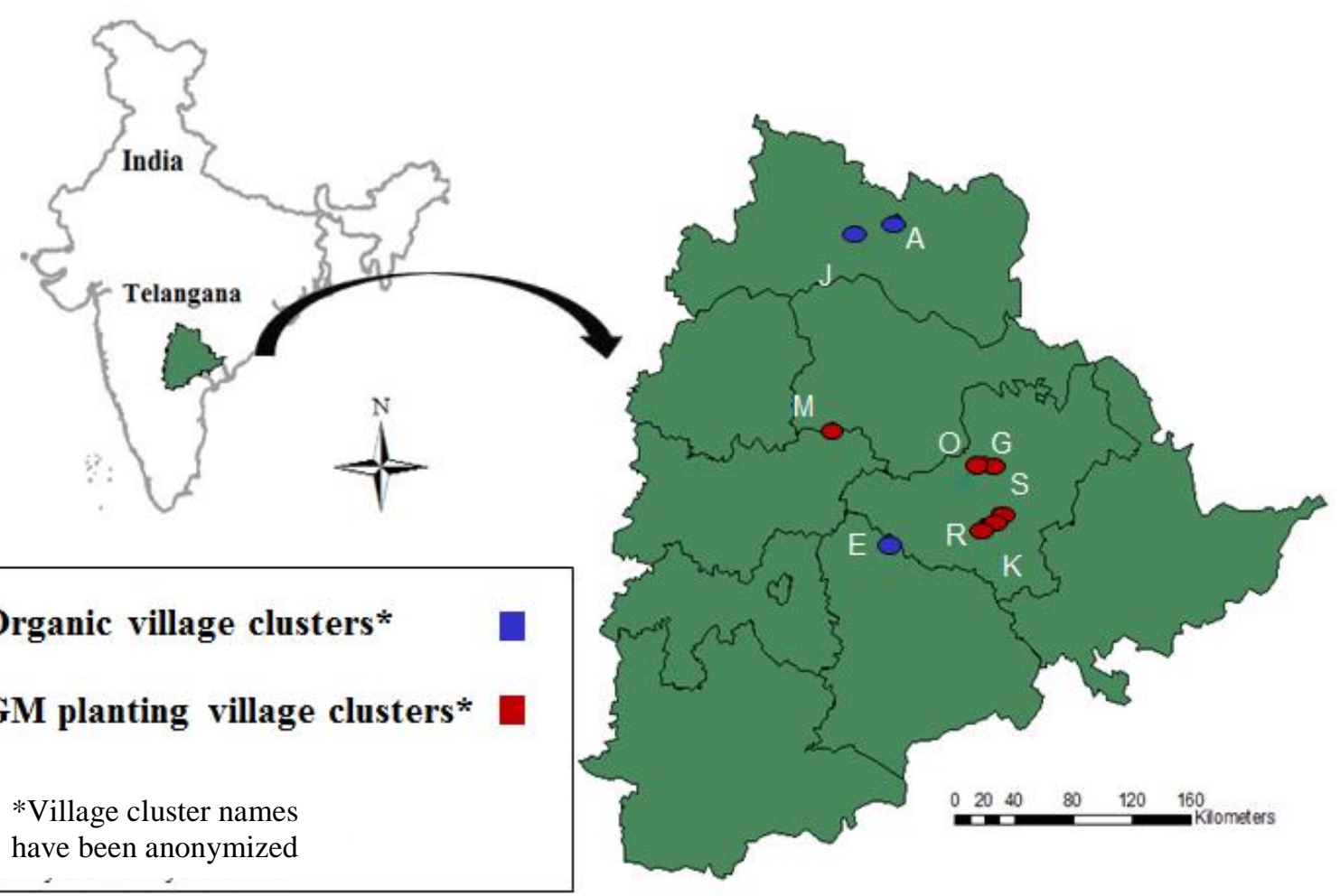

Figure 1: Telangana State and Research Village Clusters

Organic and GM regimes carry a particular set of incentives, risks, and avenues for success. Each reward structure is also dominated by a different social politics, a shifting labyrinth of those with knowledge and influence and those with uncertainty and anxiety. I focus particularly on seed choices as a synecdoche for conventional and organic smallholder farming. The knowledge, management, and reward structure of these regimes are bound up in the different commodity forms that these seeds take on, and the markets in which they are embedded. Seeds are at once a commodity to be consumed and a means of production, placing a particularly interesting set of demands on Telangana farmers. When purchased on the market as part of a GM agricultural regime or when procured through an organic program, cotton seeds, like other commodities, "represent very complex social forms and distributions of knowledge" (Appadurai 1988:41). In this case, the sociocultural baggage of a cotton seed, representing the congealed labor of biotechnologists, organic activists, and American lawyers, had to be made meaningful by Indian farmers themselves.

Postcolonial anthropology embraces such ironies, ethnographically describing the ways in which global modernity becomes "resisted, reinvented, and reconfigured in different social and historical locations" (Gupta 1998:9). Even when the regulation or technology arrives unchanged from foreign planners, farmers create new paths toward success (or failing that, toward getting by) within the reward structure of these agricultural regimes. This adaptation becomes clearest when we focus on how farmers make seed decisions under the new constraints and opportunities afforded to them by GM and organic agriculture. This article is divided into three parts. First, I contextualize GM and organic agriculture within the historical pattern of agricultural development in India post-1861. Then, I describe how farmers have reacted to emergent constraints and reward structures within new GM and organic cotton markets. I conclude by suggesting that these agricultural performances are a form of friction (Tsing 2005), by which development efforts 
unintentionally opened new avenues that allowed farmers to reap material and social benefits and allowed others to fail to do so.

\section{Three phases of development in the social life of cotton}

The colonial, green revolution, and genetically modified stages of cotton development have all been characterized by a gradual shift toward industrial logics (Fitzgerald 2003): an emphasis on profit, commodified inputs, and the consolidation of knowledge with off-farm experts. Yet despite these top-down interventions in agricultural life, each phase of development resulted in new modes of production only after a long and contentious process in which farmers themselves found ways to succeed, or failed to do so, in the new market conditions. By 1857, the enormously productive and brutal American slave economy provided nearly 70\% of the cotton spun to clothe the British Empire (Baptist 2014; Beckert 2014). However, the United States was an unreliable trade partner. It suffered enduring credit crises brought on by rampant land speculation, internal political instability, and it utilized a slave population that was illegal and unpopular in Europe. Frustrated, British landlords attempted to grow American Gossypium barbadense ${ }^{4}$ in India throughout the early $19^{\text {th }}$ century. The East India Company even hired Southern US planters to teach Indian smallholders to plant the new varieties, in a doomed 1840 extension program.

The problem was a conflict between smallholder and industrial logic. Early British-Indian cotton strains did indeed yield $25 \%$ more spinnable fiber, but only with a $200 \%$ higher cost in production capital (S. Guha 2007). This cost was unattractive for a variety of reasons. Indian smallholders, used to reliable (if inequitable) credit relationships with landlords did not see the value of such a diminished return from their labor in the name of higher profits. The rapid financing necessary for American landlords navigating a free market was less important to $19^{\text {th }}$ century Indian peasants, whose access to seasonal debts and credit was guaranteed through religious and social responsibilities (Ludden 1999; Sugata 1994). Even if farmers wished to put more energy into cotton cash-cropping they would not have been able to move their products well. India's tremendous rail and road systems had not yet reached most rural cultivators, and farmers lacked access to the transportation and storage necessary to stockpile and sell cotton on a large scale (Beckert 2014).

These incentives changed when enormous quantities of American cotton suddenly vanished from the global market in 1861 with the onset of the American Civil War. Hoping to encourage British military assistance, the Confederate government initially banned cotton exports. By the time that Confederate politicians realized that they were suffering more than their buyers, a Northern naval blockade had effectively cut off Southern trade with Europe. From 3.8 million cotton bales sent to Europe in 1860, trade fell to virtually zero by 1862 (Beckert 2014:246). British officials in India made cotton production a top priority and by 1862 India had filled this gap, providing $75 \%$ of British cotton. Organizing the crisis narrative around abolition and the liberating promises of global capitalism, India proved that cotton production could exist outside of slavery.

This shift from slave labor in the Americas to peasant sharecropping in India was accomplished by creating new credit relationships and by introducing new technology. Evolving colonial oversight simultaneously demanded quicker loan payments (Amin 1994) and relaxed fiber standards for farmers who did not want to exclusively plant unfamiliar seeds. Farmers mixed local varieties with foreign cultivars to hedge their bets with the new plants (S. Guha 2007), and by the late $19^{\text {th }}$ century, Indian farmers with a new need for cash and a new wealth of germplasm had developed a successful cross of Gossypium hirsutum, locally called 'Dharwar-American' in honor of the earlier failed extension efforts (S. Guha 2007:315). Viable cotton production had to be discovered through farmer experimentation at the edge of British-American cotton capitalism, rather than through the development schemes of the $19^{\text {th }}$ century. Only after farmers bred their own varieties within their extant agroecological system did the fruits of their labor come to dominate the global textile industry.

\footnotetext{
${ }^{4}$ Cotton exists in four domesticated species: Old World Gossypium arboreum and G. herbaceum as well as New World G. hirsutum and G. Barbadense. New World species are more pest and disease resistant and have a longer fiber length than their Old World cousins, making them genetically superior for commercial agriculture.
} 
The Green Revolution in India followed a similar trajectory, marked by the presence of new experts bringing new technology, which still had to be made meaningful in farmers' fields. In the $20^{\text {th }}$ century, India's politically embarrassing and public struggle with population numbers and famine linked its failures in production to failures of national autonomy and agricultural modernity (Bagla and Stone 2012; Gupta 1998; Perkins 1997). Promising rural development, the United States subsidized food grains to cushion the transition to new seeds, new farm inputs, and new Green Revolution crop scientists to teach farmers how to use it all (Kloppenburg 2004; Perkins 1997). The collaboration and goodwill inspired by the Green Revolution helped to strengthen ties between the two nations at a time when American geopolitics necessitated friendly relationships through South and Central Asia (Cullather 2013; R. Guha 2008; Ross 1998). As with the spread of $19^{\text {th }}$ century cotton cultivars, the implementation of this American technology required local reworking. Indian rice and wheat yields climbed through the 1970s, but only after farmers incorporated chemical inputs into their extant views of healthy field ecology and came to terms with a farm budget that saw chemical inputs as necessary commodities. Farmers came to see the resultant crops as 'weak' (Gupta 1998; Vasavi 1999), in need of pesticide and fertilizer protection. Although the Green Revolution sought to benefit the poorest, wealthier farmers disproportionately benefitted from purchasable inputs and new forms of irrigation (Shiva 1993), an inequality that the Indian state was willing to accept if it curbed underproduction (Perkins 1997; Ross 1998).

By the mid- $20^{\text {th }}$ century, wealthy farmers integrated themselves into emerging global commodity grain and textile markets, learning to turn state crop subsidies and credit to their advantage. Thus they produce the grain and fueled the industrial agribusiness that allowed agriculture ministers to declare the Green Revolution a success, even as the new agricultural logic intensified class tensions, shrank profit margins, and decreased incomes for the 75-80\% of farmers holding fewer than two acres (Cullather 2013). Poorer farmers did their best to emulate the success of those wealthy farmers, leading them to hedge their bets on new fertilizer-intensive seeds, or vote for politicians who would keep financing in place to mitigate the risk of new agrochemical technology. For those unable to make the Green Revolution shift from being land managers to modernist entrepreneurs, adaptation largely rested on new political awareness and an awkward hybridization of development and locally based knowledge. This led farmers to combine chemical inputs with applications of cow manure and non-pesticidal crop sprays made from neem seeds (Azadirachta indica) (Gupta 1998).

By the 1990s, more than a third of Indian cotton farmers grew hybrids developed by public breeding stations that yielded well only if given pesticides, fertilizers, and irrigation. Some had learned to turn the opportunities of the Green Revolution to their advantage through using hybrid chemical solutions, or through state financing plans, while others grappled with new problems of debt, chemical overuse, and a wellpublicized wave of farmer suicides (Galab, Revathi, and Reddy 2009; Gruère and Sengupta 2011; Pandian 2011; Scoones 2006). A narrative of agrarian crisis again reared its head, demanding solutions in line with India's conceptions of development. Two potential futures gained popularity as solutions to the chemical and capital-induced ills of the Green Revolution. Like their predecessors, both GM crops and organic production aimed to solve agricultural problems through new products: on one hand, a GM hybrid seed that would work within the existing system of chemicals, debts, shops, and plant scientists; on the other, a non-Bt seed that would use international Green marketing and require farmer education.

With hundreds of millions of citizens dependent on agriculture and an active civil society in India (Sainath 2013), the country has served as a barometer and trendsetter for high-tech industry and for neoliberal development models (Newell 2003; Scoones 2008; Shiva 1993). Since its independence and especially since the mid-1980s, Indian policy has fought to balance the interests of the impoverished masses championed by Mahatma Gandhi with the rising technocracy responsible for so much of India's economic growth and its geopolitical strength (Scoones 2006). In her study of international biotechnology regulation, Jasanoff (2005) notes that legislation regarding the consumption and production of genetically modified organisms in particular nations stems from their unique civic epistemology: the political culture and institutions that define how state knowledge is produced, how it is legitimated, and by what means it can be challenged. As I will demonstrate below, the ethics and politics of cotton biotechnology are inextricably 
bound to a historical precedent in which development flows from the US to India, alongside a complicated bureaucracy, a populist input, and the promise of technology.

Six years before Bt cotton would be sold anywhere in the world, Indian politicians recognized the agricultural and political potential of GMOs. In the late 1980s, the USA was the only country with a working regulatory framework for gene patenting and GM safety, and so those legal decisions were largely adapted to service Indian regulatory needs (Heinemann 2012; Newell 2003). Cognizant of the risks of upsetting rural voting blocs, and India's Green NGO sector, Indian policymakers began adapting GM regulation thirteen years before it would be legally approved for farmer use. Transgenic material would not be imported officially until 1995 or commercially released until 2002, but in 1989 Indian biotechnology advocates drafted the Rules for the Manufacture/Use/Import/Export and Storage of Hazardous Microorganisms, Genetically Engineered Organisms or Cells through the Notification No. G.S.R.1037(E). The Department of Biotechnology (DBT) drafted the Recombinant DNA Safety Guidelines in 1990 as a preemptive measure anticipating genetic modification and then updated these rules in 1998. The regulations enforced by these institutions, along with the technology itself, are drawn directly from American policies to ease the transfer of GM products and the scientists who manage them (Heinemann 2012; Newell 2003). In a set of complex accommodations designed to appease activists and business interests, these regulations created three further committees within the DBT to regulate GMOs based on different stages of the production process (Scoones 2006).

This bureaucracy, designed to split the difference between calls for oversight and for free trade, frustrated multinational company (MNC) stakeholders in biotechnology and seed distribution. In response, agribusiness groups formed loosely-connecting lobbying organizations to clarify the industry's needs to the regulators. The resulting set of complicated rules separated foreign firms, domestic seed companies, regulators, and importers, thus restricting foreign MNCs from direct investment or management. This disjuncture initially gave farmers a degree of freedom to breed seeds - Indian law is sensitive to a history of peasant exploitation, and its weak seed regulations initially provided opportunities for local companies to steal and sell patented GM seed technology (Jayaraman 2001). To make their voices heard in India, major agricultural producers like Pioneer Hi-Bred, Monsanto, and Syngenta bought subsidiary Indian companies, licensed their technology, and acquired shares in Indian distributors. Monsanto in particular negotiated commercial approval for Bt cotton in 1995 and subsequently purchased a 26 percent share in the Indian company Mayhco in 1998, to create Mayhco-Monsanto Biotech India Ltd. In doing so, it acquired a company executive with key government connections, as well as an established Indian company (Newell 2003:4).

Whereas GM regulation preceded GM production, regulation of India's organic agriculture did not coalesce until 2000, sixteen years after the first NGO-sponsored organic conference in India (Narayanan 2005). Proponents of organic farming tout its potential to cure India's chemical overuse, to halt poverty, and to bring Indian products to new markets (da Costa 2012; Panneerselvam et al. 2012). Environmentalist policymakers in the United States positioned themselves to consumers as an alternative to genetic modification and the kind of production this represented, at a time in the 1990s when environmental organizations were receiving a groundswell of support during debates over GM (Jasanoff 2005; Schmid 2007). Anti-GM activists were increasingly relevant allies. This opportunistic alliance would lead American regulators to outlaw any GMOs from organic production, thus banning them in all subsequent national and international legislation in the name of global consistency. To maintain equivalency with these standards, India's organic guidelines, like many others elsewhere in the world, have been adopted directly from USDA protocols. As such they deny certification "when use of [GM] products is detected at any stage" (Department of Commerce 2005:92). This structure mirrors the standards of the USDA and in other countries, a decision crucial for exporting Indian products to coveted markets in the US and Europe (APEDA 2012; Narayanan 2005). This equivalency has allowed the organic cotton industry to boom in India, providing $74 \%$ of the global organic cotton spun in 2012 (Textile Exchange 2013). In aligning themselves with extant American regulations, GM and organic cotton producers became legally opposed and have come to represent two mutually exclusive alternative agricultures, because of the ways that farmers use or avoid chemical pesticides and fertilizers in the management of their seeds. This opposition is especially ironic for Bt cotton biotechnologists, some of whom selected Bt specifically because of its longstanding use as a certified organic 
pesticide in the US, and they were supporters of Rachel Carson, who exposed the effects of pesticides in Silent Spring in 1962 (Charles 2001).

To reiterate, bringing India into the modern age through development has specifically involved translating law and technology from an American to an Indian context. Colonial and Green Revolution agricultural development took hold only after farmers learned to take advantage of new constraints or opportunities in the market, including government assistance (Appadurai 1996; Gupta 1998; Vasavi 1999). During the most recent agrarian crisis of the mid 1990s, brought on by the new logics of globalized cash cropping, states and corporations targeted farmers once again for a new round of development. Because of laws decided in the US, Indian cotton farmers were asked to choose between high-tech GM and low-tech organic variants.

\section{Constraint and reward under mutually exclusive regimes}

With regulation in place after 2000, input-intensive GM and internationally recognized organic production have continued in India, each receiving billions of Rupees in public and private support (The Economic Times 2010, 2012). As the first successfully commercialized GM crop, Bt cotton came to symbolize one possible future for agricultural development in India, leading organic agriculture promoters to define themselves as an alternative. Success in both instances hinges on the regimes' potential to increase income and decrease chemical use. Early advocates promoted Bt cotton and its organic alternative as a panacea for the "imagined farmers" (Freeman 2012) suffering from input overuse, debt, suicide, low yields, or from the tricks played by malicious and misleading international agribusiness. However, this analysis highlights the inconsistencies and conflicts that comprise Indian farmer adaptations and the actual adoption of these technologies. In this section I will discuss the on-farm effects that each set of laws and commodities has had on the ways that Indian cotton farmers make agro-economic decisions. Two unintended consequences of new technology, GM seed panics and organic farmer performances, challenge the sustainability of the solutions that these agricultural regimes have offered.

\section{Genetically modified Bt cotton}

Bt cotton, much maligned and praised, demonstrates many of India's agro-environmental paradoxes: the promise of high-tech modernity as well as the threat of eroded past values (Paarlberg 2001; Pearson 2006; Scoones 2008; Shiva 1997; Stone 2002); the influx of new capital and technology amid the danger of increased corporate control (Bagla and Stone 2012; Jasanoff 2005; Newell 2003; Schurman and Munro 2010; Scoones 2006); and the acquisition of new farming methods at the risk of interrupting the farming learning process (Stone 2007; Stone, Flachs, and Diepenbrock 2014). "You have to change seeds each year", Telangana farmer Arun ${ }^{5}$ told me - "...the new seeds have the best science." He is correct in a sense: seven different constructs of the Bt gene have now been released, with more coming soon to counter the omnipresent threat of insect resistance. As of 2013, the vast majority (Table 1) of these seeds contain the gene construct MON 15985, a second generation, Bt-expressing gene construct licensed by Monsanto under the trade name Bollgard II $\circledR$. MON 15985 represents the second generation of GM cotton in India, expressing two different versions of the insecticidal Cry proteins found in Bacillus thuringiensis. Additionally, numerous seeds can be sold with different brand names but identical hybrid lines, meaning that the plants in question are essentially identical but advertised differently. The Nuziveedu company, which sells seeds under subsidiary companies including Fortune Hybrid Seeds, Asian Agri Genetics, and Dhanlaxmi Crop Science, is especially guilty of selling the same NCS-207 Mallika hybrid and NCS-108 Sunny hybrid type under multiple trade names (Figure 2).

Stone (2007) called transient spikes in seed-buying behavior "fads", where as many as $80 \%$ of farmers would buy single brands only to abandon them in a three-year cycle (Stone, Flachs, and Diepenbrock 2014). Unable to keep track of these ever-changing, confusingly-labeled, and unpredictably performing seeds, farmers over-relied on social emulation and copied the seed choices of their neighbors. Foreign biotech firms

\footnotetext{
${ }^{5}$ All interlocutor names have been changed.
} 
licensed Bt technology to greater numbers of Indian seed-producing companies, allowing brands to diversify even as the actual plants did not. Monsanto supply chain lead Rama explained how these companies strategize:

It is possible in India to market the same hybrid code, same basic thing, under different brand names... Why would you want to do it? You may want to do it partly because the Indian farmer is looking for diversification. You know, even if your product is very, very good. The theory at least doing the rounds is that you know the Indian farmer never wants to put one hybrid, all eggs into one basket. Even if he's got a tiny farm of under five acres, even if it is five acres or ten acres, you take that you split it up between two, three, or four hybrids.

Even farmers seeking to diversify their seed stock in this confusing market can be stymied by this labeling. Available Bt seed brands jumped from four to fifty-one in 2005 and continued to grow every year since (Table 1), meaning that by 2012 when my study began, individual farmers could expect to see at least several hundred seed brands in a given shop. What manifested first as village-wide fads became more intense, district-wide fads by 2012, a phenomenon Stone et al. call "herding behavior" (Stone, Flachs, and Diepenbrock 2014). Seed herding has emerged from the dynamics between cotton farmers, but state government actions can also influence farmer decision-making. Political ecology asks that we pay attention to the ways that different farmers face differing levels of risk as a result of herding and fad behaviors. A scarcity of popular seeds in the Warangal district of Telangana in 2012 illustrates the risks of these seed fad patterns (Rao 2012).

\begin{tabular}{|c|c|c|c|c|c|c|c|c|c|}
\hline Gene Construct & 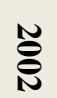 & $\stackrel{\tilde{E}}{\tilde{E}}$ & 气্ّ & $\stackrel{N}{\widehat{\sigma}}$ & 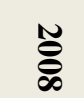 & હิ & $\stackrel{N}{\varrho}$ & $\stackrel{N}{\varrho}$ & $\overrightarrow{\stackrel{\vec{\theta}}{\vec{\theta}}}$ \\
\hline $\begin{array}{c}\text { (cry } 1 \mathrm{Ab} \text {-cry } 1 \mathrm{Ac} \text { ) "FM Cry } \\
1 \mathrm{~A}^{\prime \prime} \mathrm{G}\end{array}$ & & & & 3 & 10 & 32 & 12 & 7 & 64 \\
\hline cry $1 \mathrm{Ab}+$ Cry $1 \mathrm{Ac}$ & & & 1 & & & & & & 1 \\
\hline cry $1 \mathrm{Ab}+$ Cry $1 \mathrm{C}$ & & & 1 & & & & & & 1 \\
\hline Cry1C (Event S9124) & & & & & 2 & & & & 2 \\
\hline Fusion-Bt/GFM Cry 1A & & & & & & & & 3 & 3 \\
\hline MON 15985 & & & 7 & 10 & 53 & 130 & 42 & 256 & 598 \\
\hline Mon 531 & 3 & 1 & 38 & 50 & 43 & 53 & 34 & 8 & 230 \\
\hline Grand Total & 3 & 1 & 47 & 63 & 108 & 215 & 88 & 274 & 899 \\
\hline
\end{tabular}

Table 1: Gene constructs in Indian GM cotton seeds 2002-2011. Numbers reflect the number of new seeds approved by GEAC per specific genetic modification per year. By 2011 most new seeds contained Monsanto's Bollgard II ${ }^{\circledR}$ construct. No new constructs have been approved since.

The government of Andhra Pradesh was aware of faddish spikes in seed demand. These drive up investment costs for an already expensive crop that threatens to place its farmers in debt. In 2007, Andhra Pradesh's populist chief minister YSR Reddy led a campaign to cap license fees for Bt technology in the state. Recognizing that an added cost endorsed by the state would be better than black market theft of their technology (Herring 2007; Jayaraman 2001), Monsanto reduced the technology fee for Bt genes to Rs 150 (US\$3), down from Rs 1250 (US\$25) (The Hindu 2007). This protected farmers buying Bt seeds in shops from the price demanded by the free market, although seed costs have increased more than Rs 300 (US\$6) 
since this policy was put in place. In 2012, a spike in demand for three seeds ${ }^{6}$ from the Maharastra Hybrid Seed Company (Mahyco) and one seed ${ }^{7}$ from the Nuzivedu seed company led to shortages across the Telanagana region. The seed companies that serviced Telangana, and particularly the Warangal district, had failed to allot enough seeds to meet projected demand. The maximum retail price assigned by the state prevented shops from legally raising prices in response, and so farmers who could afford to do so rushed to Warangal city shops to pre-order seeds.
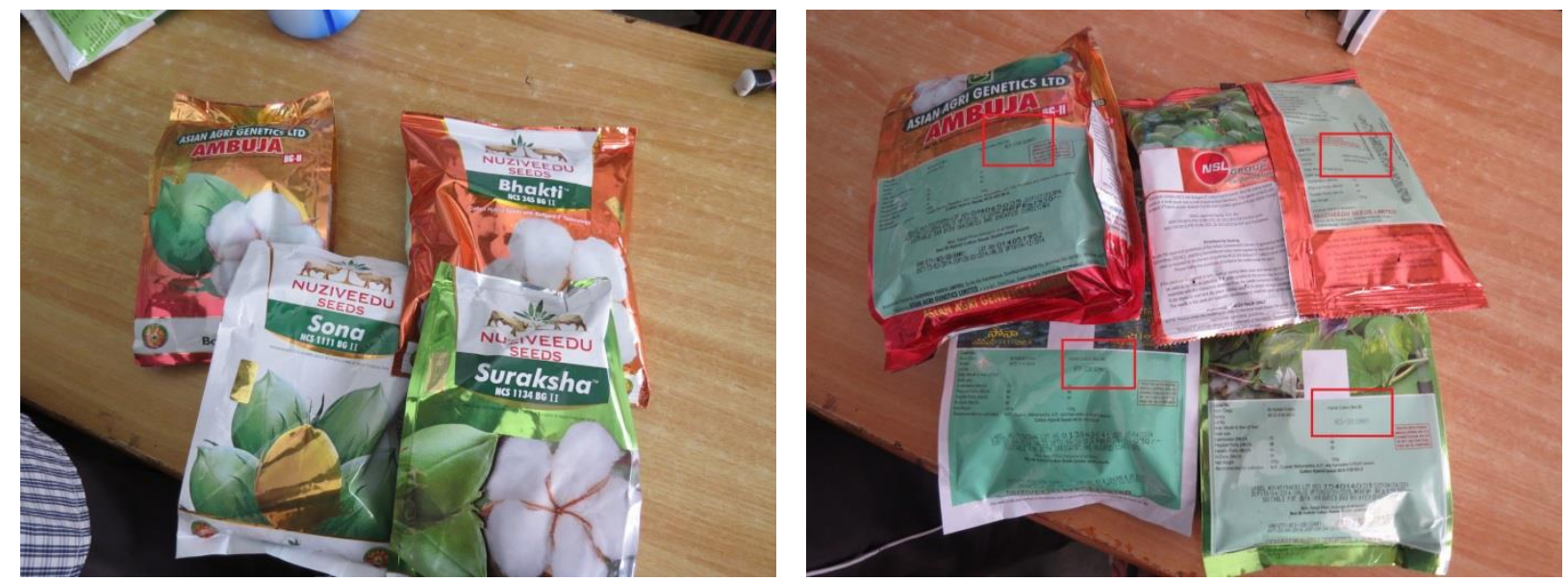

Figure 2: A Warangal seed and chemical shop pulls down the different brands of the NCS-108 Sunny hybrid type that he sells in his shop. Left: seed packet front side. Right: seed packet back side.

To control demand and to temper high market prices during this period of seed scarcity, the state government distributed permits that guaranteed a given seed's price and availability based on shop pre-orders. Permits, distributed to farmers from their local government office through a lottery system, specified a particular shop, seed brand, price, and the number of packets an individual could purchase. In this way, one farmer got one permit (Figure 3) for one package at one shop. Prices were (theoretically) controlled and sales of those four seeds without a permit were criminalized. Had Warangal district farmers and seed sellers followed these restrictions exactly, farmers who did not receive a permit or did not receive sufficient quantities of the seeds they desired would, like any rational economic actor, simply switch to another brand. This solution was, at best, uninformed of the destabilized learning that led farmers to stampede for specific seeds in the first place, as well as their willingness to circumvent the law. At worst, the perceived authority given to the seeds by government involvement sustained the fads for those seeds, and made the popular varieties seem even more elusive and desirable.

"The farmers are like ants", one Warangal shop owner observed dryly when I asked why the farmers were rushing to plant the faddish seeds. By capping the cost for these seeds far below what farmers were willing to pay, the state government unintentionally created a black market to serve those farmers without seed permits. Prices varied, but farmers could expect to pay at least Rs 2000 (US $\$ 40$ ), twice the shop rate for black market seeds that should have cost Rs 930 (US\$18.60). In 2012, the Mahyco company distributed about 6,000,000 packets $^{8}$ to the state of Andhra Pradesh, leaving a deficit of 400,000. These missing packets arrived from other districts and from the neighboring state of Maharastra, where seed supply better matched

\footnotetext{
${ }^{6}$ Neeraja (MRC 7201-BGII), Dr. Brent (MRC 7347-BGII), Kanak (MRC 7351-BGII). The trade name of the seed brand is listed first with the hybrid number given in parentheses.

${ }^{7}$ Mallika (Bt-NCS 207)

${ }^{8}$ One seed packet is sufficient to plant one acre of cotton at a "double lining" in which plants and rows are equally spaced, usually about $90 \mathrm{~cm}$ by $90 \mathrm{~cm}$. Since 2013 , many farmers have begun "single lining", in which the spacing is tighter and two packets are required to plant an acre.
} 
seed demand (Rao 2012; The New Indian Express 2012). Shop owners and farmers offered several theories to explain the supply and demand mismatch: seed growers had stolen the crop and sold it to a rival company; Mahyco was keeping the demand high and supply low in the Telangana region to encourage smuggling and extract bribes; or, agreements between the state government and Mahyco limited supply to increase demand for the Mahyco products in coming years.

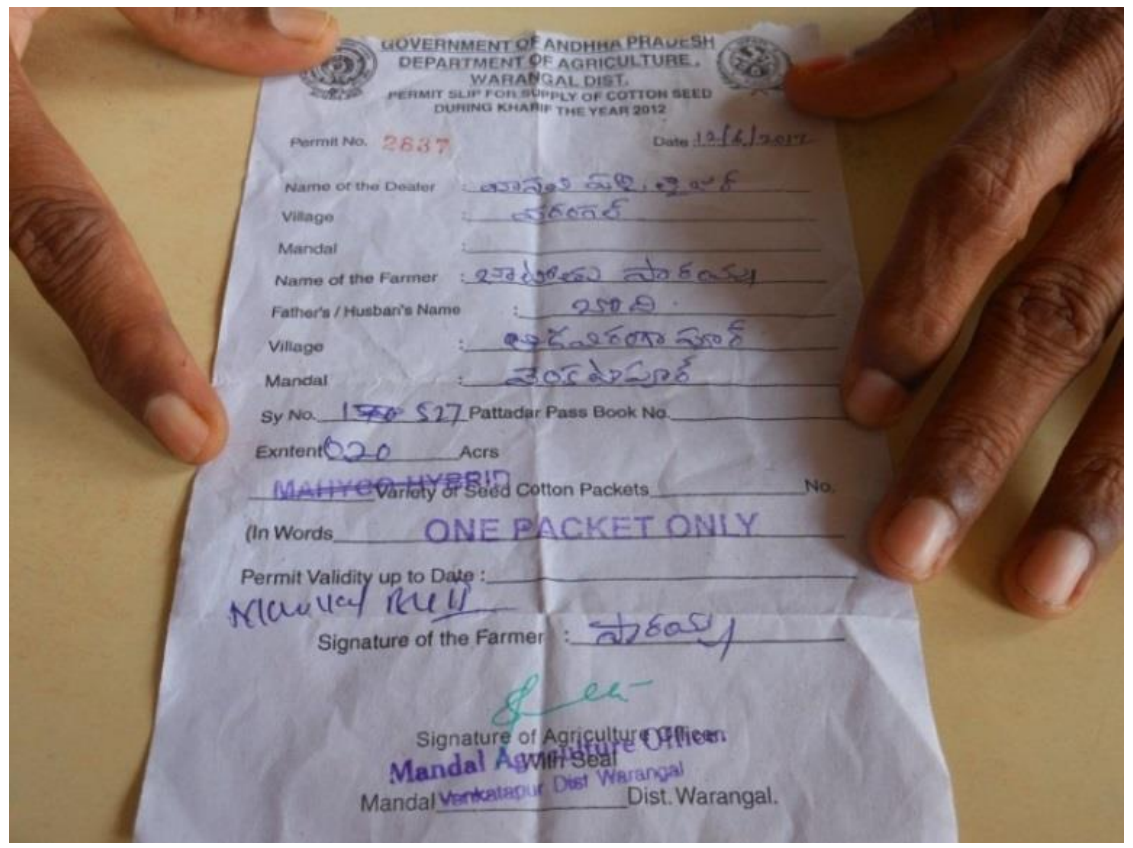

Figure 3: A Warangal seed permit for one packet of a Mahyco Hybrid.

Whatever the root cause, the permit system proved to be frustrating for seed shops that abided by government rules. Permits kept the price artificially low, which benefited farmers lucky enough to receive them. However this system also punished shop owners who made a slim profit on the most popular seeds and then watched as black market brokers capitalized on the supply vacuum. Preordering Mahyco seeds in 2012 was expensive and required shop owners to take out loans with high interest rates - the "more we invest in Mahyco, the more we lose" scoffed a Warangal shop owner in an interview. To mitigate this loss, some shop owners charged farmers extra 'transportation costs' that mysteriously disappeared from receipts. In more extreme cases shop owners sold the black market seeds themselves, although agriculture officers made enough highly publicized arrests to make shop owners wary of such obvious lawbreaking (The Hindu 2012). Frustrated with repeated seed shortages, black markets, and reports of unreliable seeds, Telangana's northern neighbor, Maharastra, first accused Mahyco of selling directly to the black market and then ultimately banned Mahyco seeds for several months (Wadke 2012).

The government chooses the seeds with price guarantee permits based on their projected popularity, but in 2012 this became a vicious cycle where people demanded popular seeds, the government limited their distribution with a permit scheme, and the resultant scarcity then caused those seeds to become even more popular. Farmers in the Warangal villages where I worked dealt with this new wrench in their seed-buying process in different ways. A farmer belonging to a Scheduled Tribe (ST) ${ }^{9}$ community complained:

\footnotetext{
${ }^{9}$ Caste and ST categories are census designations that reflect historical disenfranchisement in the caste system. These have a contemporary impact on the infrastructure and resources available to these communities. ST communities in this area live in hamlets (thandas) adjacent to villages proper, with poorer infrastructure and less access to shops and transportation routes.
} 
Those with political connections and money take the permits and the cheaper Mahyco seeds. Others see them [taking the seeds] and want them too. They pay high prices for them, and then continue to plant Dr. Brent and Neeraja [two popular seed brands in 2012] even after the plants fail because the shops sell out.

Procuring these seeds without a permit could depend on geography and ethnicity. In two villages, dominated by farmers belonging to the caste system, farmers stoically accepted the scarcity and the resulting unequal permit distribution. In another caste village, seed distribution was conducted according to the rules set by an established farm cooperative. Similarly closely-related Tribal families on the outskirts of that village distributed seeds amongst relatives. In the absence of cooperative buying behavior or kinship ties, other farmers turned to unscrupulous brokers, who were not restricted by legal or familial requirements to supply good seed at a fair price. In turning to brokers, farmers showed that they were so desperate to get a chance at 'fad' seeds that they would risk buying a more expensive one with no guarantee of its veracity. In 2012, 38\% came either from black market brokers or from people reselling black market seeds ( 89 out of the 231 seed choices by 142 cotton-planting farmers in a four village sample).

Most brokers traveled to villages, but some farmers found ways to seek out seeds themselves. Farmers with the right combination of transportation and social connections could seek out brokers, but this was rare. In one village, farmers pooled their resources with friends and neighbors to send delegates to other states and other districts where they could find the 'fad' seeds. The community paid for the smuggler's transportation and expenses as well as a modest markup, in exchange for a guarantee for their favorite brands. This could be dangerous - if border police apprehended the buyer as he crossed into Andhra Pradesh, the person would receive no help from those who sent him. Seed brokers had to deal with police checkpoints on Andhra Pradesh's Maharashtra border, leading entrepreneurial smugglers to hide seeds in containers for non-permit brands, bribe border guards, or even hide seed packets in headscarves and turbans. One broker, hastily assuring me that he only brought small, practically-legal, amounts across the border, reminded me that the high risk entailed a high reward: "...he who does not get caught will be king", he smirked.

In addition to the necessarily higher investment cost of purchasing their favorite seeds on the black market, farmers stressed two risks when buying seeds from brokers: seed resellers give no bill of sale, and they sometimes sell fake or "duplicate" (Telugu = nakkali) seeds. The problem of receipts is significant as they give cotton farmers a modicum of security. Should the seeds fail to germinate, as is likely in times of drought or unpredictable weather, they can present their bill of sale to agricultural officers who may then launch an investigation and eventually compensate farmers for lost revenue. Farmers with receipts at least have a chance to recoup their losses. When farmers buy at extra cost on the black market, they waive their right to this recourse as brokers are difficult to track down by the time that cotton germinates. This places farmers with the least access to desirable seeds at the most risk for being cheated. Poor farmers ask wealthier neighbors with connections in other states to bring seeds; they ask the higher caste neighbors on whose farms they provide labor to buy seeds; farmers living in Tribal hamlets on the outskirts of villages without regular bus access are especially likely to see these travelling brokers, and to buy their more convenient but less reliable seeds. The reverse occurrence is unthinkable in this social landscape: brokers targeting high caste households, or high caste farmers asking their laborers to pick up seeds.

This is a far cry from the descriptions of a technology needing 'no changes' on the part of the farmer (Thaindian News 2008). This is a myopic view that sees Bt cotton as an apolitical technology, rather than as an element of a marketing strategy, and of state intervention. Proponents failed to realize the ways in which farmers would cut through the confusing seed market, and this has resulted in fads and scarcities. It would be misleading to blame GM seeds themselves for causing farmer uncertainty. However, the pitfalls of the 2012 permit system illustrate how devotion to 'fad' seeds exacerbates underlying risk and complicates existing problems of farmer decision-making. In 2012, nearly $40 \%$ of these Warangal district farmers bought 
unlabeled seeds from untrustworthy people for exorbitant prices. Additionally, those same farmers had never before planted $30 \%$ of the specific seed brands they purchased, choosing them for their 'buzz' alone. Seed sales and cotton acreage increased in 2012, but farmers' knowledge about those seeds remained vague. By 2014, farmers had largely abandoned those fad seeds in favor of new ones. Such transient seed fads help to further destabilize agricultural decision-making among farmers who are already vulnerable to gaps in credit financing and unpredictable weather patterns. Seed fads allow brokers and seed companies to profit from farmers who have no way to differentiate between numerous brands.

\section{Organic cotton production}

Among organic farmers, the need for regulatory compliance has created a market for NGOs and organic corporations to translate the regulations for interested farmers in India. Designed for American farms struggling for legibility in the supermarket (Guthman 2004), USDA-equivalent certification can be expensive for Indian organic projects. Producers and farmers lack the infrastructure and access to markets that would make organic farming easier and profitable, while the benefits of this time-consuming agriculture are perceived to be limited (Eyhorn, Ramakrishnan and Mäder 2007; Panneerselvam et al. 2012). Given the need for international supply chains and accreditation, farmers in India cannot simply decide to grow organic products and market them as such. Rather, organic NGOs and corporations play a crucial role in promoting organic agricultural practices in the country because of their ability to commit the time and energy required for transition and troubleshooting (Kolanu and Kumar 2003). In doing so, they also engage farmers as stakeholders in an international movement that is mutually exclusive with GMOs.

International and domestic NGOs have begun promoting organic agriculture as an alternative development pathway resonating with Western caution toward GMOs. In adopting USDA organic regulations, Indian organic promoters found legitimacy by claiming to be an alternative to GM crops and their agricultural regime Unlike the health benefits promised to consumers of organic produce, the consumption of organic cotton rests solely on perceived benefits for growers and the ecosystem. Transparency and performance are key in this environment. The international NGO network and development organizations that fund these projects rely on success narratives, morally "transformed" farmers, and triumphant photographs for donor money or added value products (Duveskog, Friss-Hansen, and Taylor 2011). Farmers' stories become commodities sold to donors or ethical buyers wishing to invest in alternative development projects that generate new, developed subjects (Franz and Hassler 2010). Yet, just as GM seeds became faddish commodities in the hands of seed companies and black market brokers, organic farmers also make their own meaning during organic marketing. In practice, many farmers learned to perform opportunistically for visiting donors or the media, entering into a mutually beneficial relationship wherein the sponsoring program could show these farmers off to foreign visitors and potentially interested farmer converts. In exchange, these performing farmers often found that they could reap the best material and social rewards for working with organic programs.

Even with charismatic leaders who can appeal to foreign buyers or skeptical neighbors, organic agriculture suffers from yield problems. There are several difficulties involved in directly comparing organic farmer cotton yields with GM. The organic farmers were recruited because they are poorer and live on more marginal land, so one might expect them to have lower yields anyway. Additionally, while the agronomic conditions are similar between the GM and organic farmers, they live in different villages. These caveats aside, the average differences in yield, measured in 100kg bales, are stark (Figure 4). Furthermore, in a world where high yields are equated with good farming, organic farmers are well aware that their yields are below those enjoyed by their pesticide-spraying, Bt cotton-planting neighbors. During one interview, a GM-planting neighbor stopped to tease, "Why are you asking about their farms? With [Bt seed] Ajeet I am getting much better yields than these people." 


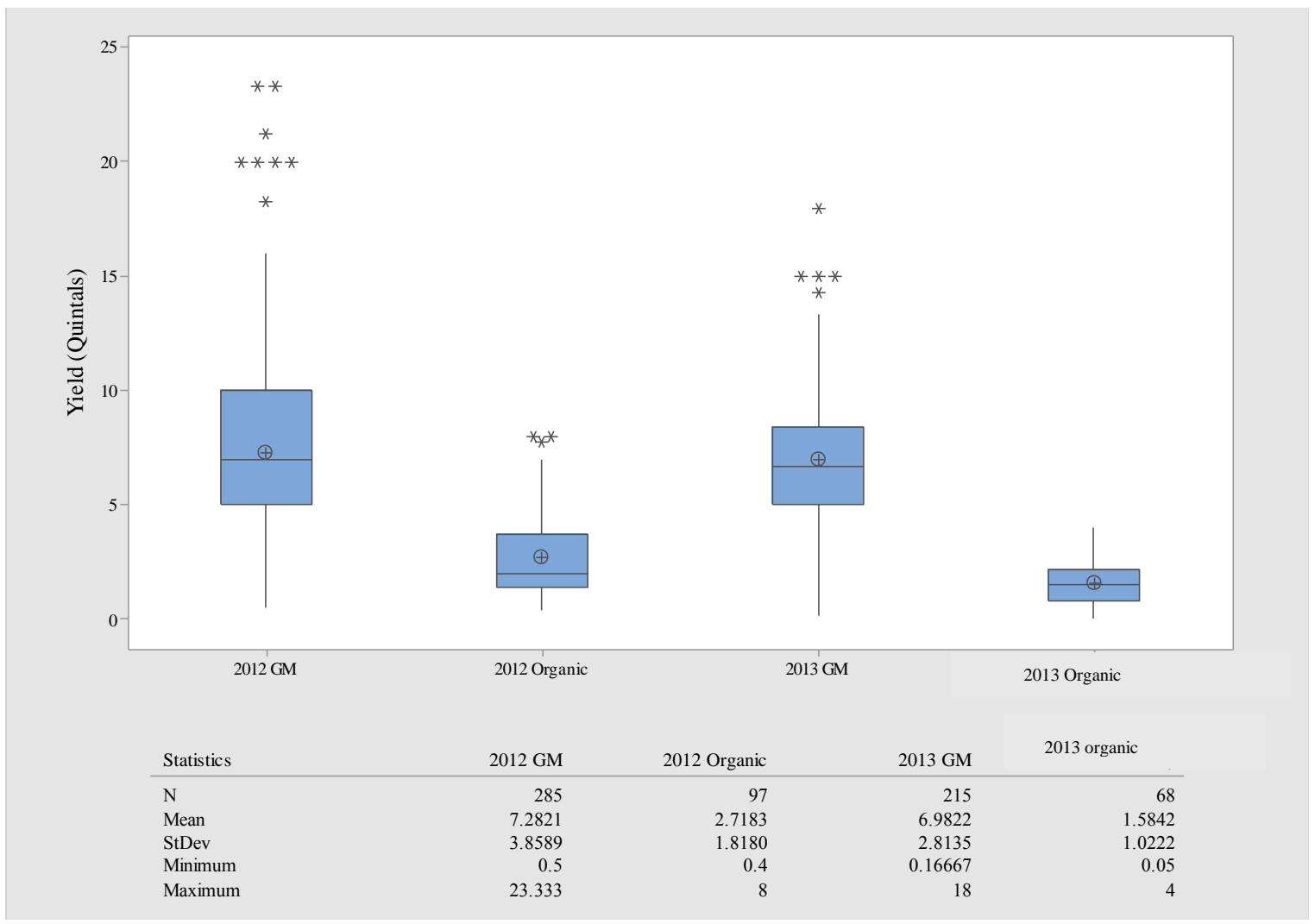

Figure 4: Boxplot of cotton yields per acre per household of organic and GM farmers. ${ }^{10}$ In each year, these differences were statistically significant at $\mathrm{p}<.001$.

To counteract low yields, organic intervention programs underwrite many production costs. In fact, most farmers in the village benefit from equipment, seeds, and access to government schemes (Figure 5). In 2012 and 2013 in these organic cotton villages, organic programs provided access to a large percentage of the seeds that farmers planted. In doing so, programs save farmers the time and trouble of an Rs 50-100 (US\$12) round-trip fare to the nearest store. Like typical seed shops, the organic providers give seeds on credit. Unlike those shops, they provide credit at low interest rates or often no-interest. These programs also provide more wiggle room during repayment than stores. Regardless of these costs, the programs that I worked with often gave seeds away for free. Given that more than $90 \%$ of the cotton planted in India is genetically modified, programs often find it easiest to provide the seeds they want farmers to plant. In addition to seeds, many farmers also secure equipment or loans through organic programs. While the government has a number of schemes designed to appeal to farmers, the inefficient and sometimes inept bureaucracy can be difficult to navigate for individual small farmers. Organic intervention programs step in to apply for benefits on their behalf, meeting with officials and providing the last steps necessary to connect farmers with money or infrastructure for which they are eligible. This helps to underwrite the risks of converting to organic production, especially at first, and even underwrites the relatively low yields.

Harder to quantify are the myriad social benefits of performing for visitors and working with organic organizations: news interviews, meeting foreigners, taking trips to cities and even to other countries to discuss organic methods, or becoming locally famous as a wise farmer. Some even make careers out of showing visitors around their fields. One farmer said: "If [the NGO] didn't tell us to do something we don't do it. They're so good to us, why would we want to change that system?" During a village tour, I had asked

\footnotetext{
${ }^{10}$ Boxplot created with Minitab 17 (Minitab Inc. 2010). Stars indicate outliers and the circled plus indicates the mean.
} 
Kanak, whose brother is employed by the NGO sponsoring their organic production, if he ever bent the rules of the organic program by using pesticides or GM seeds. Kanak unsurprisingly took the view that organic agriculture has been good to the farmers, offering advice that has brought them fame and expertise. He mentions how often he has been interviewed, that he's nearly as famous as the charismatic village leader, Mahesh, who was championed on the NGO website and in numerous news reports. "What about seeds?" I asked, trying to gauge his opinion on the free cotton seeds and accompanying management advice offered by the NGO. Through the organic program, the farmers in his village are only offered two seed types, far less than the hundreds of choices they would find in a seed shop. "Before [they came] we spent all our money and we didn't know how to plant" he answered dismissively. "We used to be stupid and plant rice only for selling, we never planned according to the seasons...they only give good seeds."

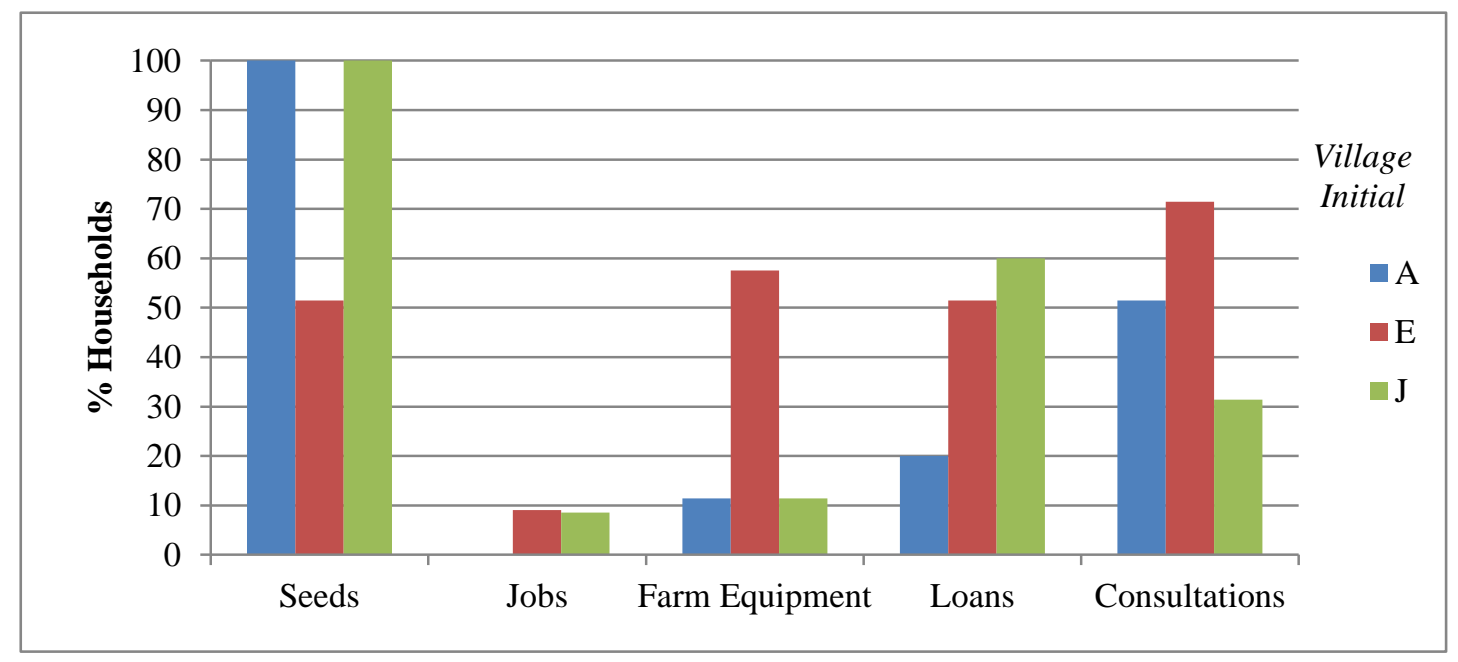

Figure 5: Percentage of households receiving material benefits from organic programs in three villages 2012-2013 $(\mathrm{n}=101)$.

I was taken aback at his suggestion that farmers didn't know how to plant and plan according to the seasons - what farmer would know so little about the fundamental agricultural input, let alone admit it? The farmer of course was performing a role, that of the transformed farmer subject. In the accompanying narrative, the village used to be a place of superstition, waste, and poor judgment. Since the intervention of the NGO, the farmers have learned to save, to eat their own products, to plan for the seasons, to be, in essence, 'good' farmers as defined by the NGO. This runs counter to the imperative felt by GM farmers to keep up with the newest and best GM seeds in order to chase the largest possible yields. While some are especially talented in securing material or social benefits, all farmers participating in agricultural development must deal with new markets and new production methods. Through this interaction they encounter a variety of experts who guard the floodgates to farm equipment, seeds, loans, and assistance programs. In this way knowledge of agricultural production, and the authority that accompanies its ownership, create relationships of deference and obligation between farmers and their respective agents of development.

The characterization of transformation as a performance is not to suggest that it is insincere. Roles must be learned and practiced, and some farmers, such as Kanak, are better performers than others. Following the work of Erving Goffman $(1959 ; 1956)$, I use performance here as a metaphor to describe how farmers have learned to portray themselves in this social environment. A performance contingent on a visiting audience allows us to account for the deference expressed when farmers talk about their knowledge to experts or visitors (Goffman 1956). On organic farms, this manifests as the socially-expected 
transformation that must be performed if farmers want to stay on good terms with the program. Goffman (1956) referred to this as a front, a performance given for the benefit of others to achieve specific social or material goals. When an organic program gives farmers seeds or subsidizes certain kinds of management, many farmers feel that it is more important to learn how to continue working with the intervention than to learn which method or seed is best. Such questions are irrelevant when the production risks are essentially underwritten by the program. However, by learning to perform, farmers can potentially find themselves speaking to crowds of politicians and movie stars in Delhi or demonstrating their methods to news teams. By learning to present the right kind of self, a transformed, scientific, business-savvy self, farmers can secure economic rewards and social recognition.

Citing farmers in various intervention programs who profess their prior ignorance of field management and business, Escobar (2011) and Agrawal (2005) note that the subjects of development adjust the way in which they talk about themselves and their work to align with the incentives and new knowledge of experts. To whatever extent that this performance breaks down under ethnographic scrutiny, farmers that I met also learned that professing transformation is the first step in a positive feedback loop: perform transformation, generate a response from the intervention program or media, attract visitors with fame and buying power, secure future assistance in the form of consultation, loans, or farm equipment, and profess to be even more transformed. This commitment to transformation is strategic and performative as it allows farmers to perform the roles expected of them by outside experts or consumers, and it is required of them if they wish to reap the benefits of working with NGO, corporate, or scientific institutions. Farmers are rewarded for projecting this ignorance, and as such it becomes part of their decision-making process in a socially embedded agricultural system.

Performance is thus highly dependent on social and economic circumstances, namely the rewards that complicate social emulation or environmental learning. The role that farmers play depends on the stage they are given. Farmers learn to perform and even embody the sense of transformation, in the presence of economic or material rewards, as well as gaining social recognition and celebrity from being regularly interviewed and photographed with visitors. This sentiment is then documented by visiting officials and researchers eager to show that their technology is not just improving farms, but improving lives. But in the absence of reliable and deliverable rewards, or in the absence of consistent and trusted oversight, the transformation of the intervention falls aside in favor of the ways that farmers learn from each other. According to a study that purported to document the "...emic perception of change in people's livelihoods" (Mancini, Van Bruggen, and Jiggins 2007:110), farmers in a village where I worked years later had learned integrated pest management (IPM) methods as part of an intervention to lower pesticide costs. After the study, those farmers reported "... an increased ability and confidence in choosing their management practices on the basis of field observations, resulting in cash savings and higher yields" (Mancini, Van Bruggen, and Jiggins 2007:106). While the farmers doubtlessly performed this transformative sentiment while working with the field school instructors, by 2012 they had largely abandoned IPM. In the words of one farmer, because "Bt came, and it gives the same benefit [of lower pesticide use] with less work." Why perform without the stage?

Especially charismatic performers may rise to the occasion because they share features of early adopters (Rogers 2003): they are more successful farmers, more interested in trying new technology, and they travel to seek out new information, or have connections to agricultural institutions. On organic farms in the three villages with organic farming where I worked, these farmers tended to be wealthier, with more land, and were highly regarded. One such farmer, Lingu is the sarpanch, or local political leader of a village in the Asifabad district of Telangana that transitioned to organic agriculture in 2007. Lingu was not the first person in the village to do so, but he quickly became a champion of farmer efforts. In 2012, program representatives asked Lingu to show off his farm when I visited. With an Rs 18,000 [US\$300] investment, Lingu was on track to net more than US $\$ 2,000$, a wide profit margin for the area. He was especially proud of his intercropping, which attracted insect pests to plants where he could spray them with homemade organic pesticides. In 2013, Lingu agreed to serve as president of the village's organic society, leading him to meet with foreign buyers who wanted to see organic agriculture in action. In 2014, the program suggested that villagers plant Johnson grass (Sorghum halepense) and mix nitrogen-fixing pulses with the cotton to aid soil 
fertility, which Lingu was obliged to demonstrate for other farmers. He planted Johnson grass on half an acre as a test plot, a small sacrifice on his ten acres. The seeds, after all, were free. "The program seems to continue to have benefits", he muses. "Since 2008 it has paid Rs 3000 [US\$50] per year to the school teacher out of the [organic added value] premiums, and that's good. Besides, if we take seeds from outside shops they'll be much more expensive." Lingu's authority as sarpanch and as a large landowner with fields close to the village made him an ideal candidate to test organic methods and oversee other farmers. While not the first adopter or most adamant champion, he saw an opportunity to benefit from subsidized seeds and he has since become a focal point for organic success in the village. These performances lead to fascinating data for the ethnographer or poignant testimonials for NGO media, but the way in which these individuals come to represent organic production generally is misleading. This elision is especially troublesome because it hides the performative aspects that make their farmwork possible - these farmers are not inherently more productive or better growers, but are sustained by a thick social network of expertise and support.

Farmers who can take advantage of these programs turn organic programs into a material safety net against their low yields. In organic villages, the initially recruited farmers are called upon to help enforce organic methods and to work with others to demonstrate new techniques. Out of necessity, they must learn to champion the skills from training exercises whether they ultimately use them in their fields or not. Like all performances, this success is contingent. About a dozen farmers dropped out of one program in 2014. I asked Baru, a former program employee, why he thought the villagers in one hamlet would stick with the program so enthusiastically while villagers less than a kilometer away would reject it. "Because of Tulanna Ram", he replied matter-of-factly. Tulanna, a paid, educated, and enthusiastic field officer born in the village helps to keep people engaged with the program. Field office visits are infrequent and more superficial where the staff don't live, and where the farmers aren't as invested to begin with. Oversight combined with material and social benefits go a long way toward easing farmers into organic production, and this cuts down on the unintended consequences of regulation. In one case, Indian organic cotton development programs were seen to increase GM cotton planting as farmers tried to hedge their bets with new organic seeds (Makita 2012). Later that year, Indian cotton raised embarrassing suspicions of widespread fraud after Swedish retailer H\&M found GM cotton in their sustainable clothing line (Graß 2013; Illge and Preuss 2012). Keeping these farmers engaged in the program is thus crucial to the green marketing that sustains (and threatens) their business.

\section{Making sense of new avenues for success within organic and GM cotton regimes}

Looking to the process by which G. hirsutum and Green Revolution strategies had to be adapted by farmers, we should expect some growing pains in these new agricultural systems. Anna Tsing (2005) has described the impact of capitalism at its margins as an awkward friction, giving rise to the myriad contradictions seen when technologies are confronted and reappropriated: the introduction of soap in Zimbabwe requiring new conceptions of hygiene and status (Burke 1996); fertilizers and pesticides reimagined in India as part of an Ayurvedic understanding of plant health (Gupta 1998; Vasavi 1999); the invocation of spirits when confronted with the cold working relationships in foreign-owned firms in Bolivia (Taussig 1980) or Malaysia (Ong 2010); and now the widespread breakdown in knowledge regarding seeds intended to improve environmental sustainability through decreased pesticide sprays (Stone, Flachs, and Diepenbrock 2014). GM and organic methods, like other technologies, must first be negotiated at the frontier of capitalism and made meaningful if they are to have staying power.

A history of agrocapitalism that sees the adoption of technology as inevitable might argue that high adoption rates of GM cotton prove GM seeds' inevitable success, or at least their inevitable integration into Telangana smallholder agriculture. This is a view of capitalism is in line with the original marketing of GM seeds, which assumed that farmers would not need to do anything differently to successfully grow cotton simply "...plant the seeds and water them regularly" (Thaindian News 2008). But this uncomplicated progression has never been true with Indian cotton capitalism, and it is a misleading narrative of agricultural modernization in the United States as well (Fitzgerald 2003; Kloppenburg 2004). A narrative of agronomic progress does not accurately describe the spread of Bt or organic cotton agriculture. Attempting to separate truth from fiction in a vast, poorly-understood seed market, most farmers are unable to trial and assess new 
technology quickly enough to draw upon their personal experience when choosing which seeds to plant. Since 2002, seeds have remained popular for an average of only three years (Stone, Flachs, and Diepenbrock 2014). Given that intimate local ecological knowledge has been shown to be crucial to sustainability, the GM seed market appears to be eroding, rather than building local efforts at sustainability. Any instability in the seed market, such as the 2012 scarcity, can drive farmers to go to extraordinary and harmful lengths to secure particular seed brands, which are abandoned the following year. As for organic seeds, farmers face much lower yields, justified largely by the non-agricultural benefits of learning to perform for visitors and officials.

In this article I have argued that organic and GM development are being made meaningful in ways that were unintended by the proponents of organic and GM cotton. Tsing calls attention to such activity as inhabiting the margins of capitalism where new meanings of commodities are born. Intended as an uncomplicated agricultural intervention (i.e. just plant and water the seed), GM seed has caused "anarchic" brand confusion and periodic lapses in knowledge where farmers scramble to buy specific seeds for one or two years, abandon them the next year, and then repeat the process the following year (Herring 2007; Stone, Flachs, and Diepenbrock 2014). Friction appears when farmers jump from seed to seed, when pro-poor technology benefits the wealthiest, and where more marginal farmers throw up their hands to demand "whatever's popular" in the shop. Intended to teach farmers new methods, organic agriculture often teaches farmers how to benefit from foreign buyers willing to underwrite their costs. These ironies are the essence of Tsing's concept of friction in the development process.

Yet farmers involved in these projects stay with them because they can use these projects to gain social or material benefits, or because they hope that the next seed fad might finally bring a good yield. By trading environmental learning for institutional savvy, or by pinning their hopes on influential village neighbors, some farmers may be losing the skills necessary to make agriculture sustainable. This is not to suggest that GM seeds are an inherently confusing technology, nor that organic agriculture is fraudulent or unsuccessful because farmers take advantage of the institutional rewards. Rather, this article calls attention to the friction inherent in development. For individual farmers, success within the political economy means taking advantage of new markets and new opportunities for facilities, and for fame.

The article has examined the social, botanical, and historical context of cotton in the Telangana region and in India generally. Since the colonial period, cotton law and technology has largely been translated from an American to an Indian context. The most recent iteration of this translation manifests in the push to create a sustainable, resilient agriculture through foreign GM or organic technology. Democracy, technocratic jockeying, and geopolitical assertion define Indian cultural politics and thus the regulation and the debates surrounding GMOs. While these conflicts have relatively banal expressions in government bureaucracy and in the lengthy imposition of official standards, they spill out into the more volatile public sphere through protests, suicides, and unprecedented levels of production and profit. This particular mix of history, governance, and the need to satisfy a conflicting set of interests has led to India's ambiguous stance on GM and organic production. Yet because all such technological efforts in agricultural development must be recognized as useful and applied to local conditions by farmers themselves, these developments also create new avenues for them to gain social or economic benefits by changing the definitions of success in agriculture. Although they are heavily mobilized in moral international debates about the future of agriculture, friction demands that farmers respond to the risks and rewards of these different technological packages that this translation requires, and situate themselves as students, wise practitioners, producers, and consumers.

\section{References}

Agrawal, A. 2005. Environmentality: technologies of government and the making of subjects. Durham: Duke University Press.

Agrawal, A. and K. Sivaramakrishnan (eds). 2000. Agrarian environments: resources, representations, and rule in India. Durham: Duke University Press. 
Amin, S. 1994. Small peasant commodity production and rural indebtedness: the culture of sugarcane in Eastern U.P. 1880-1920. In Bose, S. (ed.) Credit, markets and the agrarian economy of colonial India. New York: Oxford University Press. Pp. 81-135.

APEDA. 2012. National Programme for Organic Production (NPOP). http://www.apeda.gov.in/apedawebsite/organic/index.htm

Appadurai, A. 1988. Introduction: commodities and the politics of value. In Appadurai, A. (ed.) The social life of things: commodities in cultural perspective. New York: Cambridge University Press. Pp. 3-63.

Appadurai, A. 1996. Modernity at large: cultural dimensions of globalization. Minneapolis: University of Minnesota Press.

Bagla, P. and R. Stone. 2012. India's scholar-Prime Minister aims for inclusive development. Science 335 (6071): 907-908.

Baptist, E.E. 2014. The half has never been told: slavery and the making of American capitalism. New York: Basic Books.

Beckert, Sven. 2014. Empire of cotton: a global history. New York: Knopf.

Blaikie, P.M. 1985. The political economy of soil erosion in developing countries. New York: Longman.

Brookfield, H.C. 2001. Exploring agrodiversity. New York: Columbia University Press.

Burke, T. 1996. Lifebuoy men, Lux women: commodification, consumption, and cleanliness in modern Zimbabwe. Durham: Duke University Press.

Charles, D. 2001. Lords of the harvest: biotech, big money, and the future of food. New York: Basic Books.

Cullather, N. 2013. The hungry world: America's Cold War battle against poverty in Asia. Reprint edition. Cambridge: Harvard University Press.

da Costa, A. 2012. Organic farming promises to yield a sustainable future for India's rural poor. The Guardian, March $15 . \quad$ http://www.guardian.co.uk/global-development/povertymatters/2012/mar/15/organic-farming-india-rural-poor.

Department of Commerce. 2005. National Programme for Organic Production. New Delhi: Ministry of Commerce and Industry.

Deshpande, R.S., and Arora, S. 2010. Agrarian crisis and farmer suicides. New Delhi: Sage.

Duveskog, D., E. Friss-Hansen, and E.W. Taylor. 2011. Farmer field schools in rural Kenya: a transformative learning experience. Journal of Development Studies 47 (10): 1529-1544.

Escobar, A. 2011. Encountering development: the making and unmaking of the third world. Princeton, N.J.: Princeton University Press.

Eyhorn, F., M. Ramakrishnan, and P. Mäder. 2007. The viability of cotton-based organic farming systems in India. International Journal of Agricultural Sustainability 5 (1): 25-38.

Fitzgerald, D.K. 2003. Every farm a factory: the industrial ideal in American agriculture. New Haven: Yale University Press.

Franz, M. and M. Hassler. 2010. The value of commodity biographies: integrating tribal farmers in India into a global organic agro-food network. Area 42 (1): 25-34.

Freeman, J. 2012. How do 'imagined farmers' negotiate actual risks? Biosafety trade-offs in Bt cotton production in Andhra Pradesh, India. Journal of Political Ecology 19 (1): 162-73.

Galab, S., E. Revathi, and P. Prudhvikar Reddy. 2009. Farmers' suicides and unfolding agrarian crisis in Andhra Pradesh. In D. Narasimha Reddy and S. Mishra (eds.) Agrarian crisis in India. New Delhi: New York: Oxford University Press.

Goffman, E. 1956. The nature of deference and demeanor. American Anthropologist 58 (3): $473-502$.

Goffman, E. 1959. The presentation of self in everyday life. New York: Anchor.

Graß, T. 2013. H\&M - a role model for organic cotton use in textile processing? Journal of European Management and Public Affairs Studies 1 (1): 23-26. 
Gruère, G., and D. Sengupta. 2011. Bt cotton and farmer suicides in India: an evidence-based assessment. Journal of Development Studies 47 (2): 316-337.

Guha, R. 2008. India after Gandhi: the history of the world's largest democracy. India: Picador.

Guha, S. 2007. Genetic change and colonial cotton improvement in nineteenth and twentieth century India. In Chakrabarti R. (ed.) Situating environmental history. New Delhi: Manohar. Pp 307-323.

Gupta, A. 1998. Postcolonial developments: agriculture in the making of modern India. Durham: Duke University Press Books.

Guthman, J. 2004. Agrarian dreams: the paradox of organic farming in California. Berkeley: University of California Press.

Heinemann, J. 2012. Suggestions on how to apply international safety testing guidelines for Genetically Modified Organisms. Christchurch, New Zealand: Centre for Integrated Research in Biosafety.

Herring, R.J. 2007. Stealth seeds: bioproperty, biosafety, biopolitics. Journal of Development Studies 43 (1): $130-157$.

Illge, L. and L. Preuss. 2012. Strategies for sustainable cotton: comparing niche with mainstream markets. Corporate Social Responsibility and Environmental Management 19 (2): 102-113.

Jasanoff, S. 2005. Designs on nature: science and democracy in Europe and the United States. Princeton, N.J: Princeton University Press.

Jayaraman, K. S. 2001. Illegal Bt Cotton in India haunts regulators. Nature Biotechnology 19 (12): 10901090.

Kloppenburg, J. 2004. First the seed: the political economy of plant biotechnology 1492-2000. Madison: University of Wisconsin Press.

Kolanu, T.R. and S. Kumar. 2003. Greening agriculture in India: an overview of opportunities and constraints. Food and Agriculture Organization of the United Nations. http://www.fao.org/DOCREP/ARTICLE/AGRIPPA/658 en00.htm\#TopOfPage

Ludden, D. 1999. An agrarian history of South Asia. Cambridge University Press.

Makita, R. 2012. Fair Trade and organic initiatives confronted with Bt Cotton in Andhra Pradesh, India: a paradox. Geoforum 43 (6): 1232-1241.

Mancini, F., A.H.C. Van Bruggen, and J L.S. Jiggins. 2007. Evaluating cotton Integrated Pest Management (IPM) farmer field school outcomes using the sustainable livelihoods approach in India. Experimental Agriculture 43 (01): 97-112.

Minitab Inc. 2010. Meet Minitab 17. Minitab Inc. www.minitab.com.

Narayanan, S. 2005. Organic farming in India: relevance, problems, and constraints. Occasional Paper 38. Mumbai: Department of Economic Analysis and Research National Bank for Agriculture and Rural Development.

Netting, R. McC. 1993. Smallholders, householders: farm families and the ecology of intensive, sustainable agriculture. Stanford: Stanford University Press.

Newell, P. 2003. Biotech firms, biotech politics: negotiating GMOs in India. IDS Working Paper 201. Brighton: Institute of Development Studies.

Ong, A. 2010. Spirits of resistance and capitalist discipline: factorywomen in Malaysia. 2nd ed. Albany: State University of New York Press.

Paarlberg, R.L. 2001. The politics of precaution:genetically modified crops in developing countries. Baltimore: The Johns Hopkins University Press.

Pandian, A. 2011. Ripening with the earth: on maturity and modernity in South India. In Dube, S. (ed.) Modern makeovers: a handbook of modernity in South Asia. New Delhi: Oxford University Press. Pp $157-169$.

Panneerselvam, P., N. Halberg, M. Vaarst, and J.E. Hermansen. 2012. Indian farmers' experience with and perceptions of organic farming. Renewable Agriculture and Food Systems 27 (02): 157-169. 
Pearson, M. 2006. 'Science', representation and resistance: the Bt cotton debate in Andhra Pradesh, India. The Geographical Journal 172 (4): 306-317.

Perkins, J.H. 1997. Geopolitics and the Green Revolution: wheat, genes, and the Cold War. New York: Oxford University Press.

Plewis, I. 2014. Indian farmer suicides: is GM cotton to blame? Significance 11 (1): 14-18.

Qaim, M. 2010. Benefits of genetically modified crops for the poor: household income, nutrition, and health. New Biotechnology 27 (5): 552-557.

Qaim, M. and D. Zilberman. 2003. Yield effects of genetically modified crops in developing countries. Science 299 (5608): 900-902.

Rao, A.S. 2012. Acute shortage of Bt cotton seeds in Andhra Pradesh. India Today. June 24. http://indiatoday.intoday.in/story/acute-shortage-of-bt-cotton-seeds-in-andhra-pradesh/1/202206.html.

Robbins, P. 2004. Political ecology: a critical introduction. Malden, MA: Blackwell.

Rogers, E.M. 2003. Diffusion of innovations. 5th ed. New York: Free Press.

Roitman, J. 2013. Anti-crisis. Durham: Duke University Press.

Ross, E.B. 1998. The Malthus factor: poverty, politics, and population in capitalist development. New York: Zed Books.

Sainath, P. 2013. Over 2,000 fewer farmers every day. The Hindu, May 2. http://www.thehindu.com/opinion/columns/sainath/over-2000-fewer-farmers-everyday/article4674190.ece.

Schmid, O. 2007. Development of standards for organic farming. In Lockeretz, W. (ed.) Organic farming: an international history. Cambridge: CABI. Pp. 152-174.

Schurman, R. and W.A. Munro. 2010. Fighting for the future of food: activists versus agribusiness in the struggle over biotechnology. Minneapolis: University of Minnesota Press.

Scoones, I. 2006. Science, agriculture and the politics of policy: the case of biotechnology in India. Orient Longman.

Scoones, I. 2008. Mobilizing against GM Crops in India, South Africa, and Brazil. Journal of Agrarian Change 8 (2 and 3): 315-344.

Shiva, V. 1993. The violence of the Green Revolution: third world agriculture, ecology, and politics. Atantic Highlands, NJ: Third World Network.

Shiva, V. 1997. Biopiracy: the plunder of nature and knowledge. Boston: South End Press Collective.

Stone, G.D. 2002. Both sides now: fallacies in the genetic-modification wars, implications for developing countries, and anthropological perspectives. Current Anthropology 43 (4): 611-630.

Stone, G.D. 2007. Agricultural deskilling and the spread of genetically modified cotton in Warangal. Current Anthropology 48 (1): 67-103.

Stone, G.D. 2011. Contradictions in the last mile: suicide, culture, and e-agriculture in rural India. Science, Technology and Human Values 36 (6): 759-790.

Stone, G.D., A. Flachs, and C. Diepenbrock. 2014. Rhythms of the herd: long term dynamics in seed choice by Indian farmers. Technology in Society 36 (1): 26-38.

Sugata, B. 1994. Credit, markets and the agrarian economy of colonial India. In Bose, S. Credit, markets and the agrarian economy of colonial India. New York: Oxford University Press. Pp. 1-28.

Taussig, M. 1980. The devil and commodity fetishism in South America. Chapel Hill: University of North Carolina Press.

Textile Exchange. 2013. Farm and fiber report 2011-2012. Annual Report. Textile Exchange.

Thaindian News. 2008. Genetic engineering can help solve food crisis: US expert. Thaindian News. July 29. http://www.thaindian.com/newsportal/sci-tech/genetic-engineering-can-help-solve-food-crisis-usexpert_10077548.html. 
The Economic Times. 2010. India aims to export \$1 Bn organic products in next 5 yrs. The Economic Times. http://articles.economictimes.indiatimes.com/2010-05-15/news/27615711_1_organic-productsorganic-cotton-organic-production.

The Economic Times. 2012. Biotechnology sector to have more M\&A activity due to fund crunch: report. The Economic Times. http://articles.economictimes.indiatimes.com/2012-0215/news/31063294_1_biotechnology-sector-biotech-industry-fund-crunch.

The Hindu. 2007. Bt.cotton II price pegged at Rs. 750. The Hindu, May 5.

The Hindu. 2012. Fake cotton seed seized, one arrested. The Hindu. June 9. http://www.thehindu.com/todays-paper/tp-national/tp-andhrapradesh/article3507892.ece.

The New Indian Express. 2012. A mayhem called Mahyco seed shortage. The New Indian Express. June 25. http://newindianexpress.com/states/andhra_pradesh/article550368.ece.

Tsing, A.L. 2005. Friction: an ethnography of global connection. Princeton, N.J.: Princeton University Press. Vaidyanathan, A. 2006. Farmers' suicides and the agrarian crisis. Economic and Political Weekly 41 (38): 4009-4013.

Vasavi, A. R. 1999. Harbingers of rain: land and life in South Asia. Oxford University Press.

Wadke, R. 2012. Mahyco denies it sold its seeds in black market. The Hindu. July 15. http://www.thehindubusinessline.com/industry-and-economy/agri-

biz/article3658632.ece?homepage=true\&ref=wl_home 